\title{
新型人エ芝グランドの水文気象環境に関する 基礎的研究 \\ FUNDAMENTAL STUDY ON HYDRO-METEOROLOGICAL ENVIRONMENT OVER A NEW-TYPE ARTIFICIAL TURF FIELD
}

\author{
手計太一 1 渡辺亮一 2 - 山﨑惟義 3 ・乾真寛 4 \\ Taichi TEBAKARI, Ryoichi WATANABE, Koreyoshi YAMASAKI and Masahiro INUI \\ 1正会員 博(工) 福岡大学助教 工学部社会デザイン工学科（テ814-0180 福岡市城南区七隈8-19-1） \\ 2正会員 博(工) 福岡大学講師 工学部社会デザイン工学科（二814-0180 福岡市城南区七隈8-19-1） \\ 3正会員 工博 福岡大学教授 工学部社会デザイン工学科（†814-0180 福岡市城南区七隈8-19-1） \\ 4非会員 修士 福岡大学教授 スポーツ科学部（テ814-0180 福岡市城南区七隈8-19-1）
}

Fukuoka University constructed a football field using a new-type artificial turf with improved soil on May 2007 in order to mitigate urban heat-island phenomenon and urban flooding. To clarify hydrometeorological environment in the football field, we installed the hydro-meteorological observation system inside the football field. Furthermore, potential evaporation from the football field was measured using the model experiment.

As a result of the hydro-meteorological observation, meteorological environment over the artificial turf was analogous with environment over natural grass. In the nighttime, air temperature over the artificial turf was about 5 degree Celsius lower than in urban area. Moreover, runoff ratio of the field was $12 \%-14.5 \%$ and a lag time between peaks of a flood and a maximum rainfall was 4hours. As a result of the evaporation model experiment, evaporation rate from our proposed artificial turf system was slowly and continuously during 10 days. The new-type football field contributes to the mitigation of urban heat environment and urban flooding.

Key Words : Heat-island phenomenon, artificial turf, evaporation, urban flood mitigation, meteorological observation

\section{1. はじめに}

我が国の都市部における気温の上昇は，地球温暖化に よる気温上昇量を大きく上回り，その傾向が弱まる気配 は全く見えない(1),2). その原因は土地被覆の人為的な改 変によることは疑う余地がない3.

また，このようなヒートアイランド現象が単なる気象 現象に留まらず，気象擾乱を引き起こし，降雨強度を変 化させていると考えられている(1),5,6)，市街地における 降雨強度の増加は特に内水汇濫に繋がり, 大規模な災害 へと発展する可能性が高い.

このような都市部における水文気象学的問題に対して, 様々な対策や研究が実施されている. 例えば，屋上緑化 や保水性・透水性舗装道路の推進, 構造物に対する高反 射性塗料の利用促進等によって人工被覆物の改善対策が
実施されている7)。また，小河川や緑地を利用した風の 道の形成, その可能性については研究が進められている ${ }^{8)}$. さらに，市民による草の根的なヒートアイランド緩 和活動の一つとして「打ち水大作戦」が挙げられる ${ }^{9}$.

ところで，福岡市城南区を流れる七隈川流域では，平 成11年6月29日に発生した水害により約170戸が浸水する など甚大な被害が発生した. 現在, 河道改修が進められ ているが，河道だけでは1/10の治水安全度しか得られな いのが実情である，そのため福岡市は，流域面積の約 9. 3\%を占め，かつ河川上流域に位置している福岡大学の 敷地を利用した流出抑制対策を必要としている。

以上を鑑み，2007年5月，福岡大学は流出抑制効果や 市街地の熱環境緩和効果を期待するとともに，世界最高 峰のサッカーグランド環境を地域住民に提供することを 目的に, 保水性・浸透性の高い土壤と人体に優しい新型 の人工芝を併用したサッカーグランドを建設した. 


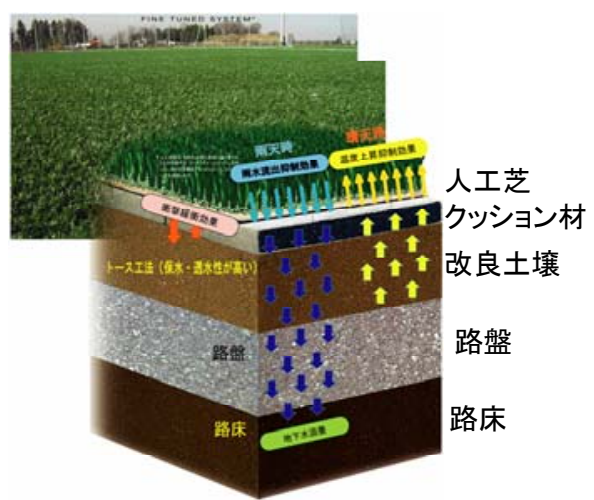

図-1＼cjkstart新型人工芝グランドの模式断面図.

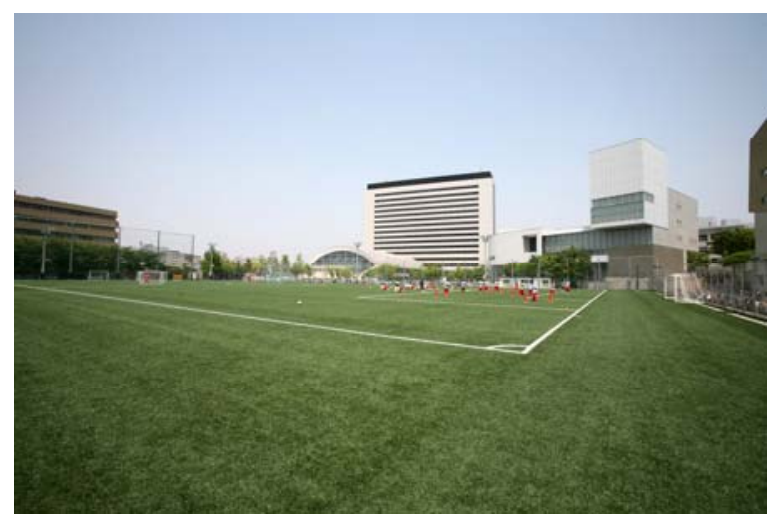

図-2＼cjkstart実際の人工芝グランドの写真.

表-1 観測項目, 観測機材, 観測期間, 観測場所の一覧.

\begin{tabular}{|c|c|c|c|c|}
\hline 観測場所 & 観測項目 (観測頻度) & 観測機材 & 観測期間 & \begin{tabular}{|c|} 
備考 \\
\end{tabular} \\
\hline \multirow{7}{*}{$\begin{array}{l}\text { 人エ芝 } \\
\text { グランド }\end{array}$} & 気温·湿度 $(1 \mathrm{~min})$ & HOBO H8 Pro(自然通風シェルター付) & 2007年6月4日～継続中 & $\begin{array}{l}\text { ※長期観測 } \\
※ \text { 観測前検定·校正済 }\end{array}$ \\
\hline & 気温·湿度(30sec) & HOBO H8 Pro(自然通風シェルター付) & \begin{tabular}{|l} 
2007年6月9日～11日 \\
2007年8月18日～20日
\end{tabular} & $\begin{array}{l}\text { ※短期集中観測 } \\
\text { ※観測前検定·校正済 }\end{array}$ \\
\hline & 全天日射量(1min) & MS-601(英弘精機社製) & 2007年7月31日～継続中 & ※長期観測 \\
\hline & 表層温度(30sec) & 3線式白金測温抵抗体センサ (T\&D Corporation社製) & \begin{tabular}{|l|} 
2007年6月9日〜11日 \\
2007年8月18日〜20日 \\
\end{tabular} & ※表面から深さ5cm \\
\hline & 表面温度(1min) & 放射温度計 (FLIR SYSTEMS社製) & 2007年8月18日～20日 & $\begin{array}{l}\text { ※54mのビル屋上より撮影 } \\
\text { ※照射角度74 14'40" }\end{array}$ \\
\hline & 雨量(10min) & 転倒栘年式雨量計 & ～継続中 & ※長期観測 \\
\hline & 表面流出量, 水位(10min) & 水位計, 量水計(コーナシステム社製) & ～継続中 & ※長期観測 \\
\hline \multirow{2}{*}{$\begin{array}{l}\text { 天然芝 } \\
\text { グランド }\end{array}$} & 気温·湿度 $(1 \mathrm{~min})$ & HOBO H8 Pro(自然通風シェルター付) & 2007年6月4日～継続中 & $\begin{array}{l}※ \text { 長期観測 } \\
※ \text { 観測前検定·校正済 }\end{array}$ \\
\hline & 気温·湿度(30sec) & HOBO H8 Pro(自然通風シェルター付) & \begin{tabular}{|l|} 
2007年6月9日〜11日 \\
2007年8月18日 20日
\end{tabular} & $\begin{array}{l}\text { ※短期集中観測 } \\
\text { ※観測前検定·校正済 }\end{array}$ \\
\hline
\end{tabular}

この人工芝グランドの建設直後より, 著者らは水文気 象観測を実施している。本稿では，新型人工芝の持つ水 文気象学的特徵を報告するとともに，新たな都市熱環境 緩和対策・流出抑制対策を提案するものである.

\section{2. 新型人工芝グランド}

一般的な人工芝グランドは，人工芝の下にアスファル 卜等の不浸透性の素材を利用しているため, 降水は速や かにグランド横の側溝に排水されていた. しかし，今回 施工された新型の人工芝グランドは透水性・保水性の高 い素材を利用しているため, 雨水を一時的に貯留する効 果があると期待されている.

本研究で対象とする新型人工芝システムの模式断面図 を図-1に示す。また，実際に施工された福岡大学仮設 サッカーグランドを図-2に示す.システム上部には我が 国では導入実績のない人工芝システム，システム下部に は保水・浸透能の高い改良土㖶を埋設している. それぞ れの詳細については以下の通りである.

\section{（1）新型人工芝システム}

本研究において対象としている人工芝は, MONDO S. p. A.（イタリヤ共和国）が開発した「モンドターフ・ ファインチューン・システム」である.

この人工芝システムは環境や人体への負荷を最小限に 抑えようと試みた画期的な人工芝である。 これは大きく
分けて3層から構成されている.

下層はファインチューンと呼ばれる廃タイヤを再利用 して製造されたマットレスである。これは衝撃吸収性を 持ち, 運動者の安全性や怪我の危険性を軽減するもので ある.また，このマットレス自身に保水力があり，一定 の湿潤性を保っている.

上層は縮小フィブリル化構造を持つ新重合体のポリエ チレン性の人工芝である。 天然芝に良く似た性能を持つ とされている. この人工芝の中にエコフィルと呼ばれる チップを充填する. このエコフィルは，一般的に使用さ れているゴムチップとは全く異なり，ゴムと樹脂がブレ ンドされた熱可塑性弾性体である. エコフィルの比重は 1.4〜 1.7 なので飛散が少なく雨水でも流出しにくい特徵 を持っている.

2006年5月，この新型人工芝はユベントスやASローマ といったイタリアの名門サッカークラブに採用され，続 いて7月にはフィンランドのフィンエアースタジアム

(国立競技場) に採用されている. ASローマとフィン エアースタジアムでは, 国際サッカー連盟（FIFA）に よる現場テストを受検し, 人工芝ピッチとしては最高レ ベルの「2スター」を取得している.

このように，上述の人工芝は運動者の安全性や機能性 については国際的に極めて高い評価を得ている.

人工芝に関する既往研究は主として，人工芝の地表面 粗度を実験的に求めた例 ${ }^{10)}$ や気象観測所において人工芝 敷設が気象観測に及ぼす影響を検討した研究11)，建物屋 上に敷設した場合における室内クーリング効果の研究な 


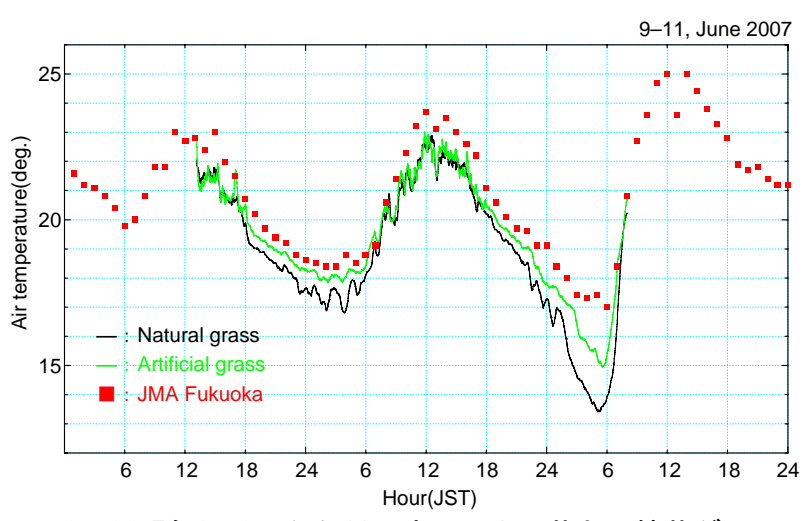

図-3 2007年6月9日から11日までの人工芝と天然芝グラン ドと福岡管区気象台ににおける気温の時系列.

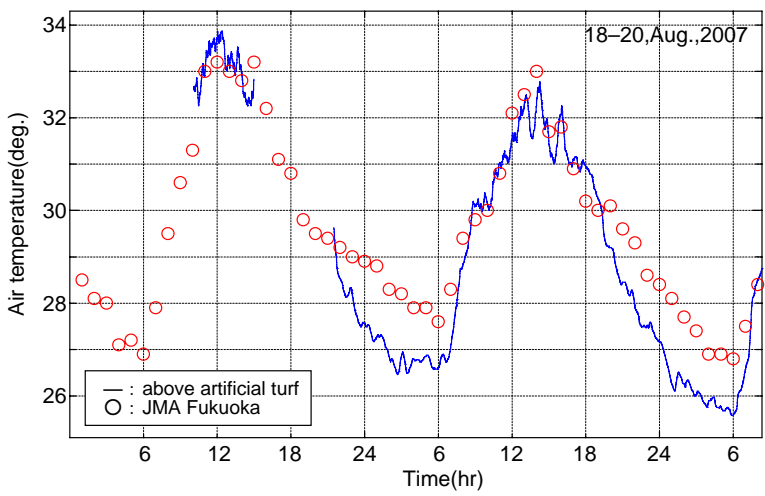

図-5２007年8月18日から20日までの人工芝上と福岡管 区気象台における気温の時系列

どである ${ }^{12)}$.

一方で，熱環境や保水性など水・熱環境についての詳 細な検証は実施されてない，特に，我が国のように高温 多湿の環境下での実証実験は全く行われていない.

\section{（2）透水性保水型工法}

本工法は，土に添加剤を配合し，土を団粒構造に変化 させることで透水性と保水性を向上させる工法として， (株シーマコンサルタント社が開発したものである.

実際の施工法は以下の通りである。まず真砂土を敷き 均し，固化剤を所定量散布しトラクターで混合する. 次 に，希釈した混和剤を散布し，さらに混合する. 最後に ローラーで転圧を行う。

本工法による改良土壤は，水はけが良く，保水による 流出抑制効果が期待できる. 一方で，使用する土は基本 的に砂質土であり，土質によっては使用できない可能性 がある。また，施工場所によっては凍害を受ける可能性 が指摘されている.

運動場等のスポーツ施設を中心に日本全国での施工実 績があるものの，強度試験の問題から車道への利用には いたっていない.

\section{3. 現地観測方法}

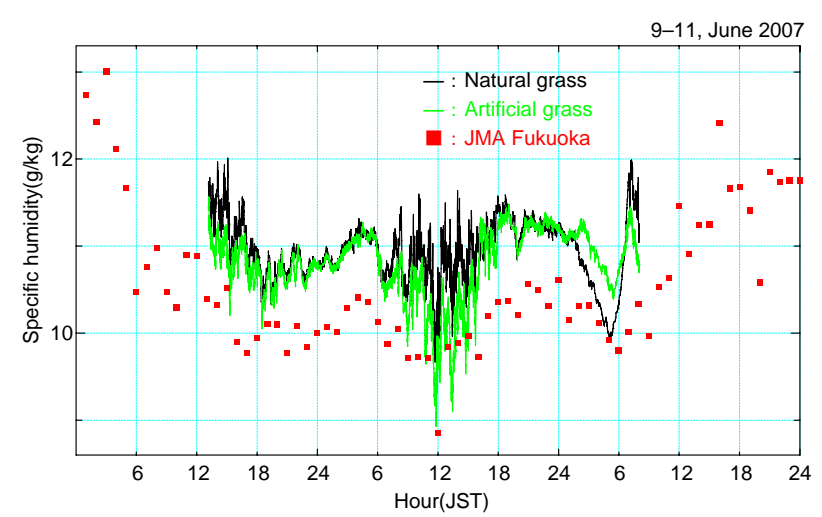

図-4 2007年6月9日から11日までの人工芝と天然芝グラン ドと福岡管区気象台にたおる比湿の時系列.

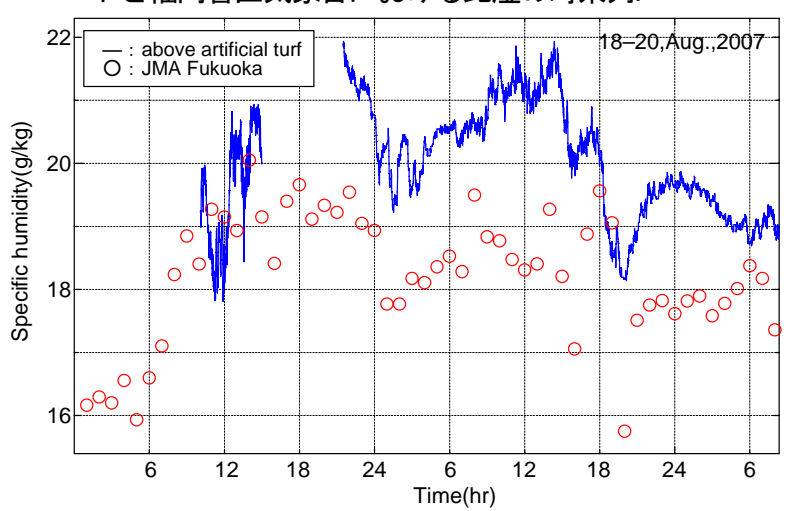

図-6２007年8月18日から20日までの人工芝上と福岡管区 気象台における比湿の時系列.

\section{（1）観測場所と比較対象}

本研究対象とする人工芝グランドは福岡大学七隈キャ ンパス内（福岡市城南区）に位置しており，その東側は 体育館，南側は約 $6 \mathrm{~m}$ の道路擁壁，西側は4階建てビルが 建っている. 北側はグランドの入口となっており，構内 道路に面している（図-2参照）。

先述したように，本人工芝グランドはサッカー用とし て建設されたものである。その広さは東西方向に $112 \mathrm{~m}$, 南北方向に78m, 面積は8763m²であり, 国際サッカー連 盟の規定を満足する広さを持つグランドである.

人工芝グランドの水文気象環境を検討するため, 約 900m離れた聖スルピス大神学院内の天然芝グランドに おいて気象観測を実施した。この天然芝グランドは多目 的広場として利用され，周囲には樹木が配置されている.

\section{(2) 観測項目 ・ 時期}

表-1に観測項目，観測機材，観測期間，観測場所を示 す.これまでに，短期集中観測を二度実施するとともに， 長期継続的にも観測している．短期集中観測では，人工 芝グランド中央に観測機材を設置し，長期観測において は人工芝グランドと構内道路との境界に設置している. また，天然芝グランドについても，集中観測ではグラン ド中央に観測機材を設置し，長期観測においては構内建 物の近傍に観測機材を設置している.

本稿では，これまでに二度実施した短期集中観測 
19, Aug. 2007 Fukuoka Univ.

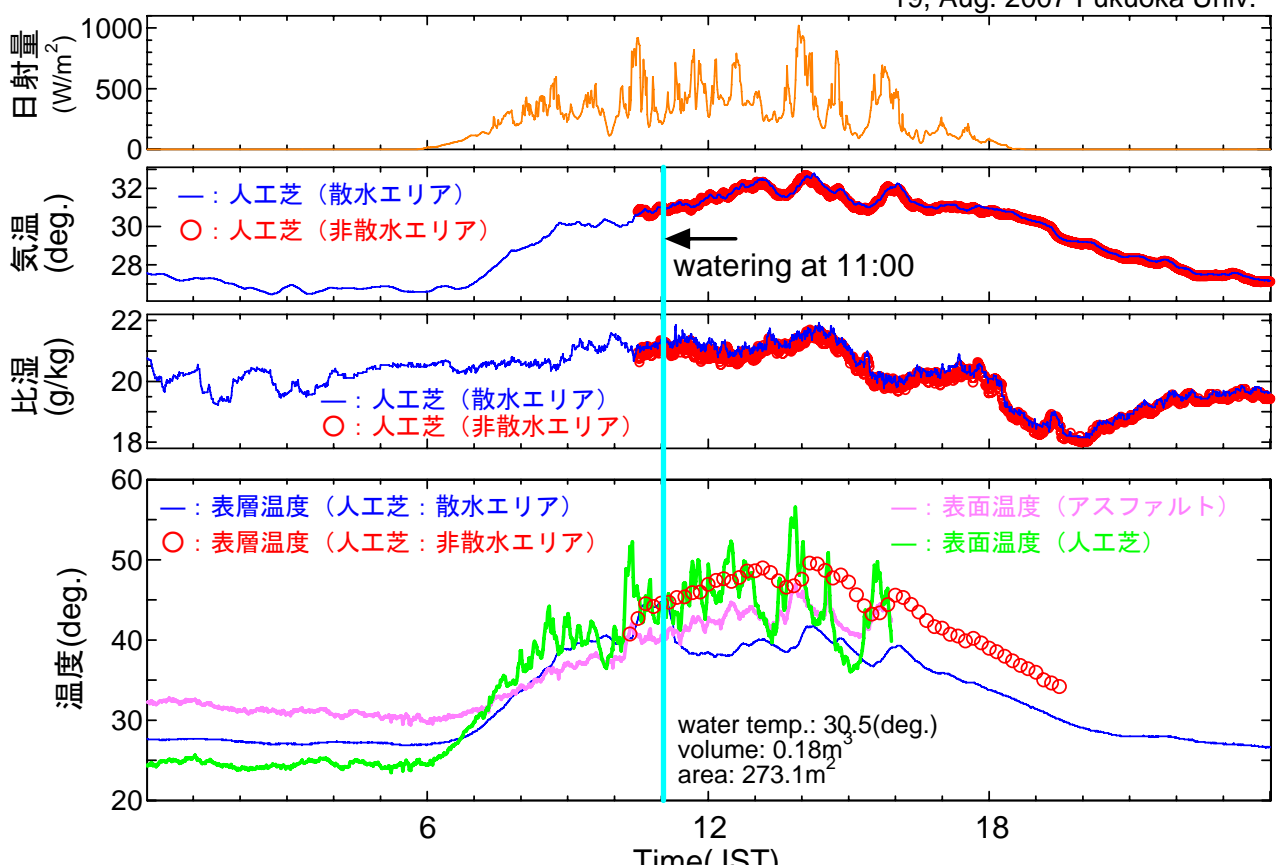

図-7 2007年8月19日の人工芝グランドにおける全天日射量，気温，比湿，表層温度，赤外放射温度 計で観測した人エ芝とアスファルトの表面温度の時系列.
図-5は2007年8月 18 日から20日までの人 工芝グランド上と福 岡管区気象台におけ る気温の時系列であ る。図-3と同様に， 両者の日中の気温は 同じ程度である。し かし，夜間の気温は 人工芝グランド上の 方が $1^{\circ} \mathrm{C}$ 以上低い.

また，長期観測の 結果においても，気 温が高い場合におい ては人工芝上・天然 芝上の気温と福岡管 区気象台のそれはほ ぼ同じであった。し かし，気温が低い場 合においては福岡管 区気象台の気温の方
（2007年6月9日から11日，2007年8月18日から20日）の 結果を中心に報告するものである.

\section{4. 現地観測結果}

\section{（1）気象環境}

図-3は2007年6月9日から11日までの人工芝グランドと 天然芝グランドと福岡管区気象台における気温の時系列 である. 全体的に，人工芝・天然芝グランド上の気温は 福岡管区気象台の気温よりも低い傾向にある，福岡管区 気象台は福岡市中心部に位置しているため, 周囲も市街 化されており気温の日変化が小さい．これはヒートアイ ランド現象に起因していると考えられる.

また，人工芝上と天然芝上の気温を比較すると，日中 の両者はほぼ同じ挙動を示している．最高気温も同程度 であり，人工芝上であっても気温がそれほど上昇しない ことがわかった。一方，夜間の気温は，天然芝上の気温 よりも人工芝上の気温の方が高く, 最大で $1.5^{\circ} \mathrm{C}$ 差で あった。これは芝の素材による影響であると考えられる が，福岡管区気象台の気温と比較すると $2^{\circ} \mathrm{C}$ 以上低い.

図-4は2007年6月9日から11日までの人工芝グランドと 天然芝グランドと福岡管区気象台における比湿の時系列 である，福岡管区気象台における比湿は，人工芝・天然 芝グランド上のそれと比較すると，全体的に低い．これ は，福岡市内の都市化による影響であると考えられる. 人工芝グランド上の比湿は天然芝グランド上のそれとほ とんど同じ挙動を示し，大気は湿った状態にあることが わかる.
が高い傾向にある.さらに，人工芝上の気温と天然芝上 のそれとは同じ挙動であった.

図-6は2007年8月 18 日から 20 日までの人工芝グランド 上と福岡管区気象台における比湿の時系列である。観測 期間を通して，人工芝上の比湿は福岡管区気象台のそれ よりも高い傾向にある。これまでの観測期間を通して, 人工芝上・天然芝上の比湿は福岡管区気象台のそれより も最大約 $2 \mathrm{~g} / \mathrm{kg}$ 高い. 市街地よりも湿潤な状態が保たれ ていることがわかる. さらに，人工芝上と天然芝上の比 湿の挙動はほぼ同じであった。この要因の一つとして, 人工芝システムの保水性による影響が挙げられる.

2007年8月19日，人工芝グランドにおいて，散水によ る気象環境の変化を捉える実験を行った。 その結果を 図-7に示す。気温がまだ上昇しつつある午前11時から約 20 分間, 水温 $30.5^{\circ} \mathrm{C}$ の水を約 $0.18 \mathrm{~m}^{3}$, 範囲はサッカー場 の北東部の一画（約 $273.1 \mathrm{~m}^{2} ）$ に散水した. 散水エリア と非散水エリアの両方に温湿度計を設置し，気温と比湿 の変化を観測した．観測日当日は快晴であったものの， 薄雲がかかっていたので日射量の時間変化は大きかった. 散水エリアと非散水エリアの気温と比湿を比較すると, 大きな変化は見られなかった．散水した面積が小さく， 水量も少なかったことが影響していると考えられる.

\section{（2）表面温度特性}

一般的な人工芝の表面温度は非常に高くなることは知 られており，人工芝競技場の問題とされてきた，そこで， 本研究対象としている人工芝グランドの表面温度につい ても検討を行った.

本稿においては，赤外放射温度計で測定した人工芝表 
面の温度を「表面温度」，熱伝対を利用して測定した人 工芝表面から約 $10 \mathrm{~cm}$ 深さにあるエコチップと砂が交 わる層の温度を「表層温度」と定義する.

前項で示した図-7の最下図に，散水した人工芝と散水 していない人工芝の表層温度の時間変化，赤外放射温度 計で撮影した人工芝とアルファルト面の表面温度の時系 列を示寸. 散水エリアの表層温度は散水直後に急激に低 下寸るとともに，温度が低い状態を長時間にわたって維 持している. 散水エリアと非散水エリアにおける表層温 度差は最大で $10^{\circ} \mathrm{C}$ 以上であった．表層温度の低下は，人 工芝上の運動者一の輻射熱を減少させる効果がある。そ してその効果の持続時間が極めて長い.

また，人工芝の表面温度と表層温度を比較すると，18 日の日中は両者とも約 $60^{\circ} \mathrm{C} て ゙$ 同じあったものの，19日は 日射量の変化に伴い表面温度も変化しており, 表層温度 との差は $5^{\circ} \mathrm{C}$ 程度ある. 夜間における人工芝の表面温度 は，表層温度よりも約 $5^{\circ} \mathrm{C}$ 低い。これは，エコチップに よる保温効果によるものと考えられる.

人工芝とアスファルトの表面温度を比較すると, 最高 温度は人工芝の方が約 $5^{\circ} \mathrm{C}$ 高い。一方夜間においては, アスファルトの方が約 $8^{\circ} \mathrm{C}$ 高く, 日没から翌日の日の出 まで続いている.これは両者の熱容量の違いが影響して おり，人工芝による夜間の熱環境緩和効果は期待できる ものと考えられる.

\section{（3）雨水流出抑制効果}

先述したように, 本研究対象グランドには雨量計を設 置し, 表面流出を捉えるために水位計を整備し，大きな 出水時には人的観測を実施している．観測しているのは， 人工芝表層からの流出量とさらにその下層の改良土壤中 からの流出量（本稿では「伏流水」と定義する）である. これらは合わせて直接下水に流れるものであり，これを 抑制させる必要がある.

図-8は2007年7月1日から10日までの降水量，表面流出 量高, 伏流水量の時系列である. 伏流水量の挙動に着目 すると，ピークが緩やかである場合やピーク時間がずれ ていることがわかる．7月2日の出水（総雨量 $70 \mathrm{~mm}$ ）で は, 降水量のピークと表面流出のピークは40分の時間差 がある．また流出率は $12 \%$ と極めて小さい．また，7月6 日から7日にかけて発生した梅雨前線による大雨（総雨 量145.5mm）のケースにおける流出率は14.5\%であった。 いずれの降雨イベントにおいても, 直接流出量は極めて 小さく, 流出抑制に大きく貢献していると考えられる. 15 20mm程度の保水力があると仮定すると, 降水量の 約60〜 70\%が地下水涵養に寄与寸ると推算できる.

\section{5. 新型人工芝の蒸発量に関する実験的検証}

前章において，新型人工芝グランドの水文気象環境に

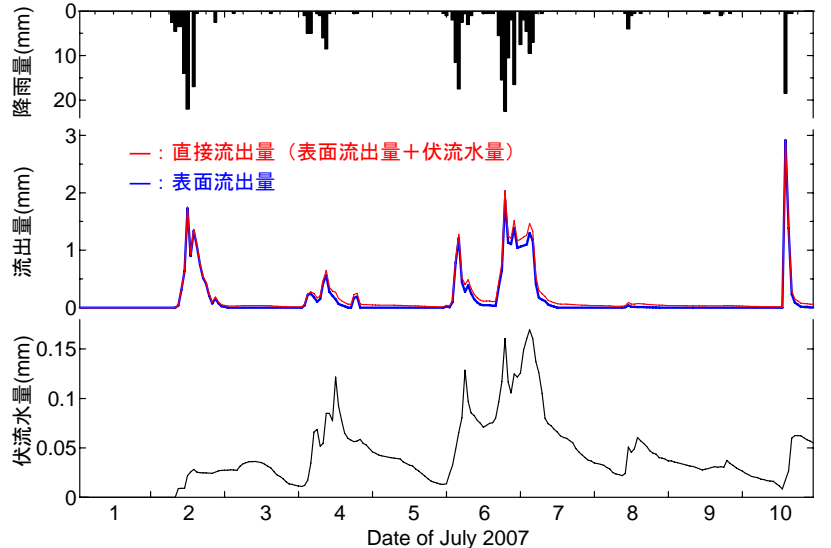

図-8 2007年7月1日から10日までの人工芝グランドにおけ る降雨量, 表面流出高, 伏流水量の時系列.

ついての現地観測結果を示した. その中で，グランド内 の比湿が高いことを示した. その要因として，人工芝や 改良土壌のもつ保水能力が考えられるため, $20 \mathrm{~cm}$ 角の サッカーグランドの模型を製作し, 蒸発量の時間変化を 実験的に検証した.

まず，底面から排水できる $20 \mathrm{~cm}$ 角のアクリル容器に 改良土壤を充填し, サッカーグランドと同程度の転圧を 掛けた。比較対象として，一般の真砂土に同程度の転圧 をかけたものを準備した（非改良土壌）。改良土壌につ いては，二種類の異なる真砂土を利用した（Type Aと B）。模型作成時における転圧は手作業で実施したため, Type AとBの模型には若干の密度差が生じた. Type Aの 密度は2.849g/ $/ \mathrm{cm}^{3}$, Тype Bの密度は $2.886 \mathrm{~g} / \mathrm{m}^{3}$ であった。 これら三種類の土猿が飽和状態になるまで散水し, 外気 にさらし重量を測定することで蒸発量を算出した，その 結果と日射量, 気温の時系列を図-9に示寸，実験直後は， 土㙵表面付近の水分が蒸発するので，いずれの土壤とも 蒸発量は同程度であった. しかし実験二日目の午後から， 非改良土壤からの蒸発量はType AとBのそれよりも大き くなり，実験三日目にはほとんど蒸発しなくなる，一方， 非改良土壤は気象条件に応じて蒸発している. Type Aと Bは共に, 実験四日目以降も一日約20gの蒸発を続けて いる. このことから, 改良土䁃は表層付近の水分が蒸発 した以降，ゆっくりと継続的に蒸発を続けていることが わかる.

次に, 上述の三種類のうち改良土壌の一つ (Type A) と非改良土壌の上に, サッカーグランドと全く同じ人工 芝を敷いて，上述と同様の実験を実施した。模型の構造 は図-1に示すような実際と路床以外は全く同じである. また，土㙥面は人工芝に完全に覆われている，その結果 と土壌下面からの浸透水量と日射量の時系列を図-10に 示す. 先述したように，人工芝と土壤の間にはクッショ ン材が入っている，それによって，水が一時的に溜まっ た状態になり, Type Aは20時間にわたり浸透水量が観測 されたと考えられる．人工芝があることで土壌への直射 


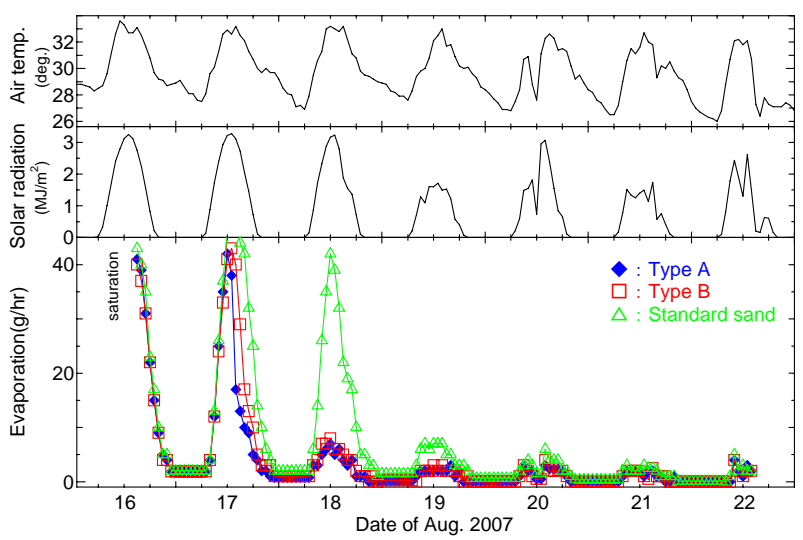

図-9 模型実験による蒸発量，気温，日射量の時系列.

日光が遮られ，蒸発量が抑制されている。しかし，実験 期間10日間にわたって，ほぼ一定の蒸発量が観測された。 その理由として，(1)人工芝底面やクッション材に水が溜 まっている，(2)改良土畩の団粒構造による保水効果の二 点が挙げられる.

以上から，人工芝システムや改良土畩に蓄えられた水 分はゆっくりと継続的に蒸発していることがわかり，人 工芝グランドの比湿が高い一因であると考えられる.

\section{6. 結論}

都市の熱環境緩和や流出抑制効果を期待して建設され た新しい人工芝を利用したグランドの水文気象環境につ いての基礎的な観測と実験を実施した。 その結果ヒート アイランド現象緩和効果と雨水流出抑制効果について大 きな期待ができるとがわかった，それぞれについて以下 にまとめを示す.

\section{（1）ヒートアイランド現象の緩和効果}

本研究対象人工芝グランドは天然芝上と同程度の気象 環境にあることがわかった。夜間の気温や表面温度は非 常に低く，ヒートアイランド現象の抑制に繋がるものと 考えられる. また，この人工芝グランドは，日射量や気 温には大きく左右されずに，ゆっくりと継続的に蒸発す ることが確認された.これがグランドを湿潤な条件にさ せているものと考えられる.

\section{（2）雨水流出抑制効果}

新しい技術を応用して建設されたサッカーグランドは 直接流出量を抑制する能力があり，地下水涵養に大きく 貢献することができる．地域の洪水汇濫抑制に大きな期 待ができるものと考えられる.

最後に，維持管理やコストを考えると，天然芝よりも 人工芝の方が有利であることは良く知られており，さら に本研究によって科学技術的な有効性も証明された. 新

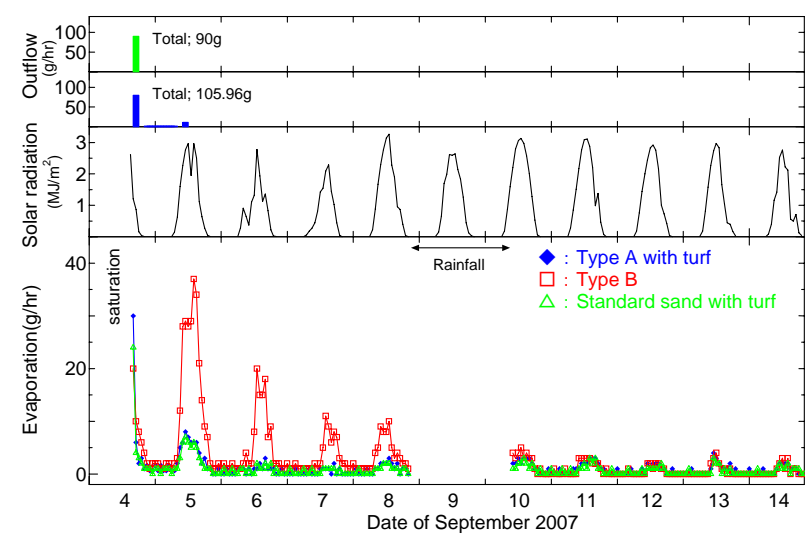

図-10人工芝を被せた模型実験による蒸発量，浸透量， 日射量の時系列

型人工芝システムと保水性土壌を組み合わせることは, 都市の熱環境や流出抑制に効果的な技術であり，広く普 及されることを切望する.

謝辞 : 本研究の遂行に際し, MONDO S. p. A., クリヤマ株 式会社，株式会社シーマコンサルタントに多大なる協力 をしていただいた。 また, 聖スルピス大神学院に天然芝 グランドの観測場所を提供していただいた。観測や実験 に際し, 福岡大学工学部水圈システム研究室の学生諸氏 の協力を得た．合わせてここに記して謝意を表します。 最後に, 本研究課題は福岡大学と福岡市との協力連携に 関する協定に基づいて実施されたものである.

\section{参考文献}

1) 気象庁: 20世紀の日本の気候, 財務省印刷局, 116pp.

2) 鬼頭昭雄: 地球温暖化と都市化による気温変化について，天 気, 51, pp.93-94, 2004.

3）下田吉之, 澤木昌典, 松本邦彦, 松村暢彦: 土地利用シナリ オにもとづく流域の将来像（ヒートアイランド現象を例 に），環境科学会誌，20, pp.225-231, 2007.

4) 藤部文昭: 東京における降水の空間偏差と経年変化の実態— 都市効果についての検討一，天気，45, pp.7-18, 1998.

5) 神田学, 井上裕史, 鵜野伊津志: “環八雲” の数值シミュ レーション，天気，47, pp.11-24, 2000.

6) 藤部文昭: ヒートアイランドが降水に及ぼす影響一夏の刘流 性降水を中心にして一, 天気, 51, pp.25-30, 2004.

7) 山本桂香: 都市におけるヒートアイランド現象の緩和対策, 科学技術動向, 54, pp.21-34, 2005.

8) 木内豪, 前村良雄, 伊藤将文: 都市河川之周辺市街地の熱環 境の実態一目黒川を事例に一, 土木学会年次学術講演会講 演概要集, II-086, 2007.

9) 狩野学, 手計太一, 木内豪, 榊茂之, 山田正: 打ち水の効果 に関する社会実験と数値計算を用いた検証，水工学論文集， 48, pp.193-198, 2004.

10)石崎発雄，桂順治，谷池義人，丸山敬: 地表面粗度の違いに よる境界層気流性状の変化に関する風洞実験, 風工学シン ポジウム論文集，Vol.8, pp.91-98, 1984.

11)前田勝彦, 山下晃弘: 大瀬戸地域気像観測所の人工芝敷設に よる気温の変化について, 気象庁研究時報, Vol.50, pp.202203, 1998.

12)阿部敏雄，尹聖睆，足永靖信: 蒸発・日射反射による建物屋 上面の冷却効果に関寸る実験的研究，環境の管理，No. 50 , pp.79-84, 2004.

(2007. 9. 30受付) 